\title{
Tanggungjawab Pemerintah Dan Pelaku Usaha Makanan Siap Saji Terkait Penggunaan Wadah Plastik Yang Berbahaya Bagi Konsumen Di Kota Ambon
}

\author{
Agustina Balik ${ }^{1}$, Vica Jilyan Edsti Saija ${ }^{2}$ \\ ${ }^{1}$ Dosen Fakultas Hukum Universitas Pattimura, Ambon, Indonesia \\ E-mail:balikgusti@yahoo.co.id \\ ${ }^{2}$ Dosen Fakultas Hukum Universitas Pattimura, Ambon, Indonesia \\ E-mail:justitia_power@yahoo.com
}

\begin{abstract}
Plastic containers are the most popular food packaging materials used. Many businesses choose plastic as a container for their products, because the plastic has excellent properties such as: strong but light, practical, cheap and not out of date. Though it use is very dangerous because can happen migration of chemicals from plastic to food wrapped especially in the heat. The role of BPOM (Food and Drug Supervisory Agency) and the Office of Industry and Trade on Consumer Protection has not been effective in socializing the dangers of using plastic as a food packaging container. The research method used is the normative juridical research method to examine the legal material, the provisions of positive law, legal principles, legal principles and legal doctrine to answer the legal issues faced. The form of supervision is part of the function and at the same time is the responsibility of BPOM and the Office of Industry and Trade in the field of Consumer Protection in an effort to provide protection to the community. demanded knowledge and awareness of business actors in choosing containers used to wrap food to be purchased by consumers. Responsibility on the basis of an error may be imposed on a business actor if the business actor makes a mistake that harms another person. While the absolute responsibility of direct business actor is responsible as business risk. Therefore, for a business actor who uses a plastic container that is harmful to human safety, he or she may be held liable for damages.
\end{abstract}

Keywords: responsibility, government, business actors, dangerous plastic containers

\section{A. PENDAHULUAN.}

Kemajuan di bidang industri yang kian pesat berefek pada timbulnya era pasar bebas, yang membuat persaingan antar produsen semakin ketat terutama untuk menarik konsumen terhadap berbagai macam produk yang ditawarkan 
produsen. Dengan kondisi yang demikian, maka bisnis merupakan kegiatan yang integral dari kehidupan masyarakat yang modern. Kondisi pasar yang diwarnai persaingan ketat dan bervariasinya produk yang ditawarkan, akhirnya menempatkan konsumen sebagai subyek yang memiliki banyak pilihan. Menghadapi realitas tersebut, konsumen didorong untuk semakin menyadari hak-haknya. Kesadaran tersebut semakin berkembang dengan adanya gerakan konsumen global yang mencoba melakukan protes terhadap pelaku usaha yang merugikan hak-hak konsumen. ${ }^{1}$

Wadah Plastik merupakan bahan kemasan pangan yang paling populer digunakan. Banyak pelaku usaha yang memilih plastik sebagai wadah bagi produk mereka. Hal ini karena plastik memiliki sifat-sifat unggulan seperti: kuat tetapi ringan, tidak berkarat, bersifat termoplastis, yaitu dapat direkat dengan menggunakan panas, serta dapat diberi label atau cetakan dengan berbagai kreasi. Selain itu plastik juga mudah dirubah bentuk. $^{2}$

Produsen yang membuat plastik sebagai bahan kemasan makanan dan minuman harus memenuhi Standar Nasional Indonesia. Namun demikian, dalam kenyataannya produsen plastik banyak yang tidak memberikan informasi tentang plastik yang aman digunakan sebagai kemasan makanan dan minuman. Untuk itu, banyak konsumen yang tidak atau kurang mengetahui cara penggunaan kemasan yang baik untuk kemasan makanan dan minuman serta bahaya yang dapat ditimbulkan akibat penggunaan yang salah.

Kemasan produk plastik dibuat dari

\footnotetext{
1 Endang Sri Wahyuni, Aspek Hukum Sertifikasi dan Keterkaitannya dengan Perlindungan Konsumen, PT.Citra Aditya Bakti, Bandung, 2003, hlm.158

2 Sutrisno Koswara, "Bahaya Dibalik Kemasan Plastik", <ebookpangan.com>, diakses pada tanggal 25 Februari 3-17
}

beberapa golongan atau jenis plastik. Contoh golongan plastik: ${ }^{3}$ plastik dengan kode 1 dan 7 atau PET (polyethylene terephthalate), biasanya plastik jenis ini dipakai untuk botol plastik, berwarna jernih atau transparan atau tembus pandang seperti botol air mineral, botol jus, dan hampir semua botol minuman lainnya. Plastik dengan kode 2, 4 dan 5 atau HDPE (high density polyethylene), biasanya dipakai untuk botol susu yang berwarna putih susu, tupperware, galon air minum, kursi lipat, dan lain-lain. HDPE merupakan salah satu bahan plastik yang aman untuk digunakan karena kemampuan untuk mencegah reaksi kimia antara kemasan plastik berbahan HDPE dengan makanan/minuman yang dikemasnya. Disamping PET atau HDPE, pembuatan plastik mengandung pula zat berbahaya yang digunakan sebagai bahan pembuat kemasan plastik misalnya penggunaan styrofoam, plastik tipis (cling wrap) dan kresek hitam. Styrofoam termasuk golongan plastik yang sangat dilarang untuk terkontaminasi panas karena mengakibatkan perpindahan bahan-bahan kimia yang berbahaya ke dalam makanan. ${ }^{4}$

Pada umumnya, berbagai lapisan masyarakat sebagai konsumen menggunakan plastik sebagai bahan kemasan pada produk makanan dan minuman. Dalam kehidupan sehari-hari, masyarakat menggunakan plastik sebagai bahan utama pembungkus makanan tanpa memperhatikan cara penggunaannya akibat ketidaktahuan akan bahaya penggunaan yang salah. Hal ini dapat kita jumpai pada pedagang-pedagang makanan siap saji yang berada di pinggiran jalan dan para pelaku usaha

\footnotetext{
3 http://pengetahuan umum.wordpress.com, diakses pada tanggal 25 Februari 2017

4 Sapto Nubroho Adi, “Ancaman polimer Sintetik Bagi Kesehatan Manusia", http://www.chem-is-try.org/?sect=articel\&ect= $\underline{69}$, diakses pada tanggal 25 Februari 2017
} 
restoran yang menyediakan makanan atau minuman yang dikemas dengan plastik.

Terkait dengan hal ini, pemerintah telah memberi perhatian terhadap arti penting dari pangan dan keamanan pangan dengan mengeluarkan Undang-Undang Nomor 18 Tahun 2012 tentang Pangan (selanjutnya disingkat UUP). UUP secara khusus mengatur bahwa pangan yang digunakan konsumen harus dalam keadaan aman disebut dengan keamanan pangan. Salah satu yang termasuk dalam keamanan pangan adalah produksi pangan, pengemasan pangan dan pengedaran makanan. Dengan demikian pemerintah harus menegaskan kriteria produk plastik yang aman dan melarang penggunaan golongan plastik yang beresiko merugikan konsumen. Peran aktif pemerintah dalam melakukan pengawasan, pengaturan dan perlindungan terhadap kepentingan konsumen akibat kelalaian pelaku usaha dalam menggunakan produk plastik yang berbahaya sangatlah penting.

Dalam hal pengemasan makanan siap saji, banyak pelaku usaha di kota Ambon menggunakan wadah plastik yang berbahaya. Hal ini disebabkan karena kurangnya informasi dan pengetahuan terkait penggunaan produk plastik yang aman untuk makanan dan minuman. Padahal informasi penggunaan kemasan dari produsen pembuat kemasan plastik merupakan suatu kewajiban sebagai langkah awal untuk mencegah akibat buruk penggunaan plastik yang salah.

Kewajiban memberi informasi yang benar dan jujur atas setiap produk yang dihasilkan oleh produsen atau pelaku usaha merupakan salah satu kewajiban utama yang diatur dalam Undang-Undang Nomor 8 Tahun 1999 tentang Perlindungan Konsumen (selanjutnya disingkat UUPK). Pada prinsipnya, UUPK lahir dalam rangka memberikan jaminan kepastian hukum bagi konsumen terhadap segala bentuk pelanggaran dari produsen atau pelaku usaha yang menimbulkan kerugian bagi konsumen termasuk bahaya atau kerugian yang mungkin timbul akibat penggunaan kemasan plastik yang salah.

Berdasarkan UUPK, salah satu hak konsumen adalah berhak atas kenyamanan, keamanan, dan keselamatan dalam mengkonsumsi barang dan/atau jasa. Untuk itu dalam hal penggunaan kemasan plastik seharusnya pelaku usaha menjalankan kewajiban dengan baik sehingga konsumen akan memperoleh hak berupa keamanan dalam mengkonsumsi pangan yang aman dari bahaya melalui informasi yang benar dan jujur dari pelaku usaha.

Peran Pemerintah dalam melindungi konsumen ditunjukkan dengan mendirikan Badan Perlindungan Konsumen Nasional (BPKN) merupakan lembaga yang dibentuk tahun 2004 oleh pemerintah dan berada langsung di bawah Presiden. Tugas BPKN antara lain mengkaji berbagai kebijakan perlindungan konsumen, menyusun dan memberikan saran serta rekomendasi kepada pemerintah, menyebarluaskan informasi melalui media mengenai perlindungan konsumen dan memasyarakatkan sikap keberpihakan kepada konsumen, serta menerima pengaduan dari masyarakat. Namun di kota Ambon BPKN ini tidak ada. Pada Dinas Perindustrian dan perdagangan ada salah satu bidang yang menangani upaya perlindungan konsumen, yaitu bidang perlindungan konsumen, tetapi pengawasan yang mereka lakukan hanyalah terhadap produk-produk yang berlogo atau tidak berlogo SNI (Standar Nasional Indonesia). Selain itu, ada juga satu lembaga non kementerian yang berfungsi memberikan pengawasan yang menyeluruh terhadap pembuatan dan peredaran pangan yang dikonsumsi konsumen yaitu Badan Pengawas Obat dan Makanan (selanjutnya disingkat BPOM). BPOM dibentuk melalui Keputusan Presiden (Keppres) Nomor 
166 Tahun 2000 yang disempurnakan dengan Keppres Nomor 103 Tahun 2001. Berdasarkan Pasal 68 Keppres Nomor 103 Tahun 2001 disebutkan tentang fungsi BPOM yang terkait dengan pengawasan suatu produk antara lain menyusun serta melaksanakan kebijakan tertentu di bidang pengawasan obat dan makanan.

BPOM mempunyai tugas melaksanakan tugas pemerintahan di bidang pengawasan obat dan makanan sesuai dengan ketentuan peraturan perundang-undangan yang berlaku, dalam memberikan perlindungan kepada masyarakat di bidang obat dan makanan. Dalam hal ini, BPOM provinsi Maluku telah melakukan berbagai langkah yaitu dengan memberikan informasi-informasi kepada para konsumen tentang kemasan plastik yang baik digunakan untuk kemasan makanan dan minuman, tetapi langkah BPOM ini belum efektif karena masih banyak pelaku usaha atau konsumen di kota Ambon yang tidak mengetahuinya sehingga tetap menggunakan kemasan plastik sebagai kemasan makanan dan minuman yang dapat membahayakan kesehatan konsumen. Berdasarkan latar belakang tersebut, maka permasalahan yang akan dibahas adalah “ Bagaimana Tanggungjawab Pemerintah dan Pelaku Usaha Makanan Siap Saji Terkait Penggunaan Wadah Plastik Yang Berbahaya Bagi Konsumen Di Kota Ambon"

\section{B. PEMBAHASAN}

\section{Gambaran umum Penggunaan Wadah Plastik Oleh Pelaku Usaha Di Kota Ambon}

Wadah plastik merupakan bahan kemasan pangan yang paling populer digunakan. Banyak pelaku usaha yang memilih plastik sebagai wadah bagi produk mereka. Hal ini karena plastik memiliki sifat-sifat unggulan seperti: kuat tetapi ringan, tidak berkarat, bersifat termoplastis, yaitu dapat direkat dengan menggunakan panas, serta dapat diberi label atau cetakkan dengan berbagai kreasi. Selain itu plastik mudah dirubah bentuk. $^{5}$

Berdasarkan hasil observasi atau pengamatan yang dilakukan oleh peneliti terkait penggunaan wadah plastik yang khususnya digunakan oleh pelaku usaha makanan siap saji dan restoran di kota Ambon, maka dapat diuraikan beberapa hal sebagai berikut:

a. Di kota Ambon terdapat banyak pelaku usaha makanan siap saji yang kegiatan usahanya beraneka ragam. Mulai dari usaha restoran, warung makan, dan usaha rumahan yaitu penjual lauk pauk (makanan jadi), penjual jajanan di pinggir jalan baik yang menggunakan mobil, gerobak maupun yang hanya dengan tempat seadanya (meja kecil).

b. Waktu penjualannya beraneka ragam. Ada yang hanya pagi hari, ada yang dari pagi sampai malam, dan ada juga yang hanya malam hari.

c. Masyarakat pembeli atau konsumen makanan siap saji ada yang langsung menikmati makanannya ditempat dia membeli, namun tidak sedikit juga yang membelinya untuk dibawah pulang.

d. Kemasan pembungkus yang dipakai oleh pelaku usaha makanan siap saji berfariasi. Ada yang masih menggunakan daun pisang dan daun rit yang masih tradisional (hanya sedikit saja pelaku usaha yang menggunakannya), ada yang menggunakan kertas nasi (biasa untuk makanan yang tidak berkuah). Namun dibandingkan dengan pembungkus-pembungkus makanan yang disebutkan, maka penggunaan

\footnotetext{
Sutrisno Koswara, Op.cit, $<$ ebookpangan.com>, diakses pada tanggal 25 Februari 3-17
} 
plastik dan Styrofoam yang lebih banyak digunakan oleh pelaku usaha sebagai wadah pembungkus makanan (makanan yang panas maupun yang dingin, yang berkuah maupun yang tidak berkuah).

e. Masyarakat pembeli atau konsumen makanan siap saji yang membeli makanan untuk dikonsumsi di rumah tidak mempersoalkan wadah yang dipakai untuk membungkus makanan.

Inilah beberapa hal pokok yang ditemukanan oleh peneliti dalam melakukan observasi atau pengamatan terhadap pelaku usaha makanan siap saji di kota ambon. Selain observasi atau pengamatan yang dilakukan, peneliti juga melakukan wawancara terhadap pelaku usaha, konsumen dan pemerintah (Balai Pengawas Obat dan Makanan BPOM dan Dinas Perindustrian dan Perdagangan Provinsi Maluku Bidang Perlindungan Konsumen).

a. Hasil wawancara dengan Pelaku Usaha $^{6}$

1. Terkait dengan berapa lama mereka berjualan, waktunya relatif. Ada yang baru beberapa bulan, ada juga yang sudah bertahun tahun.

2. Wadah yang dipakai untuk membungkus makanan, banyak yang menggunakan plastik atau Styrofoam. Alasannya, mudah didapat, murah, ringan, praktis.

3. Terkait pengetahuan pelaku usaha tentang bahaya penggunaan wadah plastik untuk membungkus makanan, ternyata ada pelaku usaha yang sudah tahu namun ada juga yang belum tahu. Bagi pelaku usaha yang sudah tahu bahayanya namun masih tetap memakai, rata-rata alasan mereka adalah karena wadah itulah yang sekarang ini mudah didapat dan harganya murah serta sudah tidak ketinggalan zaman,

6 Wawancara dengan beberapa pelaku usaha makanan siap saji di kota Ambon, tanggal 4 November 2017 dibandingkan dengan menggunakan daun pisang atau daun rit. Selain itu konsumen juga tidak pernah merasa keberatan dengan wadah plastik yang digunakan. Ada juga konsumen yang membawa sendiri wadah dari rumah untuk membungkus makanan.

4. Terkait dengan sosialisasi penggunaan wadah plastik yang berbahaya oleh BPOM maupun Dinasi Perindustrian dan Perdagangan Bidang perlindungan Konsumen, pelaku usaha belum pernah mendapatkan sosialisasi maupun himbauan secara tatap muka langsung. Hanya sekedar melihat lewat panflet atau baliho yang dipasang dipinggir jalan.

b. Hasil wawancara dengan Konsumen ${ }^{7}$

1. Banyak konsumen yang mengkonsumsi makanan siap saji, terutama bagi mereka yang memiliki tingkat kesibukan yang tinggi sehingga tidak punya banyak waktu untuk memasak di rumah. Mereka akhirnya lebih memilih membeli makanan siap saji. Hanya sedikit konsumen saja yang membawah wadah dari rumah, sebagian besar menggunakan wadah plastik atau Styrofoam yang disiapkan oleh pelaku usaha.

2. Tidak sedikit konsumen yang sudah tahu bahaya penggunaan plastik untuk membungkus makanan apalagi makanan yang panas. Namun karena faktor kondisi, misalnya: karena aroma makanan yang menggoda, kondisi perut yang sudah lapar, atau lupa membawah wadah, membuat konsumen tetap membeli makanan walaupun mereka tahu wadah yang dipakai untuk membungkus makanan itu adalah plastik atau Styrofoam.

\footnotetext{
7 Wawancara dengan beberapa konsumen makanan siap saji di Kota Ambon, tanggal 4 November 2017
} 
c. Hasil wawancara dengan Kepala Balai Pengawas Obat dan Makanan ${ }^{8}$

BPOM mempunyai tugas melaksanakan tugas pemerintahan di bidang pengawasan obat dan makanan sesuai dengan ketentuan peraturan perundang-undangan yang berlaku, dalam memberikan perlindungan kepada masyarakat di bidang obat dan makanan. Bentuk pelaksanaan fungsi dan peran mereka yaitu berupa himbauan, sosialisasi dan edukasi kepada pelaku usaha. Terkait dengan penggunaan wadah plastik sebagai pembungkus makanan siap saji, menurut kepala BPOM Propinsi Maluku cakupan pengawasan yang dilakukan oleh BPOM hanya terhadap olahan pangan berkemasan, obat-obatan farmasi maupun tradisional, dan kosmetik. Terkait dengan penggunaan wadah plastik sebagai wadah pembungkus makanan bukanlah merupakan cakupan pengawasan mereka. Namun ketika BPOM melakukan himbauan, sosialisasi dan edukasi, para penyuluh lapangan juga memberitahukan dampak penggunaan plastik untuk membungkus makanan walaupun itu bukan prioritas utama mereka karena bukan cakupan pengawasan BPOM.

Artinya bahwa himbauan, sosialisasi maupun edukasi yang dilakukan BPOM prioritas utamanya bukan pada penggunaan wadah plastik sebagai pembungkus makanan tetapi hanya pada olahan pangan berkemasan, obat-obatan farmasi maupun tradisional, dan kosmetik.

d. Kepala Bidang Perlindungan Konsumen pada Dinas Perindustrian dan Perdagangan Propinsi Maluku ${ }^{9}$

8 Wawancara dengan Kepala Balai Pengawasan Obat dan Makanan Propinsi Maluku, tanggal 6 November 2017

9 Wawancara dengan Kepala Seksi Perlindungan Konsumen Dan Pengawasan Barang Dan Jasa Dinas Perindustrian dan Perdagangan,
Terkait dengan penggunaan wadah plastik sebagai media pembungkus makanan siap saji, bukan merupakan kewenangan Bidang Perlindungan Konsumen pada Dinas Perindustrian dan Perdagangan Propinsi Maluku untuk melakukan pengawasan maupun memberikan tindakan tegas bagi para pelaku usaha. Hal ini karena tugas pokok dan fungsi mereka hanyalah melakukan pengawasan kepada pelaku-pelaku usaha yang menjual produk-produk baik itu plastik, melamin, dll yang sudah berstandar SNI (Standar Nasional Indonesia). Bagi pelaku usaha yang kedapatan menjual produk yang tidak berstandar SNI akan diberikan teguran. Kalau sampai teguran itu tidak diindahkan maka Bidang Perlindungan Konsumen pada Dinas Perindustrian dan Perdagangan Propinsi Maluku akan menyita produk-produk yang tidak berstandar SNI dari peredaran.

\section{Tanggungjawab Pemerintah Dan Pelaku Usaha Makanan Siap Saji Terkait Penggunaan Wadah Plastik Yang Berbahaya Bagi Konsumen}

Menurut kamus besar Bahasa Indonesia, Tanggung jawab adalah kewajiban menanggung segala sesuatunya bila terjadi apa-apa boleh dituntut, dipersalahkan, diperkarakan. Dalam kamus hukum, tanggung jawab adalah suatu keharusan bagi seseorang untuk melaksanakan apa yang tepah diwajibkan kepadanya. 10 Menurut hukum, tanggung jawab adalah suatu akibat atas konsekuensi kebebasan seseorang tentang perbuatan yang berhubungan dengan etika dan moral dalam melakukan suatu perbuatan. ${ }^{11}$

\footnotetext{
Hafsah Abdullah, tanggal 1 November 2017

10 Andi Hamzah, Kamus Hukum, Ghalia Indonesia, 2005, hal 10

11 Soekidjo Notoatmojo, Etika dan Hukum Kesehatan, Rineka Cipta, Jakarta, 2010,
} 
Selanjutnya menurut Titik Triwulan pertanggungjawaban harus mempunyai dasar, yaitu hal yang menyebabkan timbulnya hak hukum bagi seseorang untuk menuntut orang lain sekaligus berupa hal yang melahirkan kewajiban hukum orang lain untuk memberikan pertanggungjawabannya. ${ }^{12}$

Menurut hukum perdata pertanggungjawaban dibagi menjadi dua, yaitu kesalahan dan resiko. Dengan demikian dikenal dengan pertanggungjawaban atas dasar kesalahan (liability without based on fault) dan tanggungjawab tanpa kesalahan (liability without fault) yang dikenal dengan tanggungjawab resiko atau tanggungjawab mutlak (strick liability). Prinsip pertanggungjawaban atas dasar kesalahan mengandung arti bahwa seseorang bertanggungjawab karena ia melakukan kesalahan yang merugikan orang lain. Sebaliknya prinsip tanggungjawab resiko adalah bahwa konsumen penggugat tidak diwajibkan lagi melainkan produsen tergugat langsung bertanggungjawab sebagai resiko usahanya. ${ }^{13}$

Balai Pengawasan Obat dan Makanan (BPOM) adalah salah satu Lembaga Pemerintah Non Kementerian (LPNK) yang bertugas mengawasi obat, obat tradisional, suplemen kesehatan, kosmetik dan makanan, serta pengawasan terhadap bahan berbahaya di wilayah Indonesia. Tugas, fungsi dan kewenangan BPOM ini diatur dalam Keputusan Presiden Nomor 103 tahun 2001 tentang kedudukan, tugas, fungsi, kewenangan, susunan organisasi dan tata kerja lembaga pemerintah non departemen yang telah diubah dengan Peraturan Presiden Nomor

hal 15

12 Titik Triwulan dan Shinta Febrian, Perlindungan Hukum Bagi Pasien, Prestasi Pusaka, Jakarta, 2010, hal 48

13 Jhon Pieris dan Wiwik Sri Widiarty, Negara Hukum dan Perlindungan Konsumen, Pelangi Cendekia, Jakarta, 2007, hal 19
3 tahun 2013 tentang perubahan ketujuh atas Keputusan Presiden Nomor 103 tahun 2001. ${ }^{14}$

Bentuk pengawasan merupakan bagian dari fungsi dan sekaligus merupakan tanggungjawab BPOM sebagai pemerintah dalam upaya memberikan perlindungan kepada masyarakat. Tanggungjawab yang dimaksudkan disini bukanlah tanggungjawab berdasarkan kesalahan maupun berdasarkan resiko, karena BPOM tidak berkedudukan sebagai produsen atau konsumen. Sehingga tanggungjawab yang diharapkan disini adalah berupa pengawasan.

Bentuk pengawasan yang dilakukan oleh BPOM Propinsi Maluku yaitu: ${ }^{15}$

a. Pengawasan Preventif

Semua bentuk kegiatan sosialisasi yang dilakukan bertujuan untuk membangun pengetahuan, pemahaman sikap, dan kesadaran hukum masyarakat Maluku terkait dengan perlindungan konsumen.

Menurut BPOM Propinsi Maluku bahwa perlindungan konsumen merupakan tanggungjawab semua pihak yaitu Pemerintah, pelaku usaha, organisasi konsumen dan konsumen. Tanpa adanya andil dari keempat unsur ini maka tidaklah mudah mewujudkan kesejahteraan konsumen.

b. Pengawasan Represif

Pengawasan represif berupa pengawasan yang dilakukan oleh BPOM untuk menjamin diperolehnya hak konsumen dan pelaku usaha. Disamping itu juga pembinaan. Hal ini sesuai dengan ketentuan yang tercantum dalam pasal 30 UUPK yang menyatakan bahwa:

14 Nurhayati Abbas, Tanggungjawab Produk Terhadap Konsumen dan Implementasi pada Produk Pangan, AS Publishing: Makassar, 2011, hal 90

15 RENSTRA BPOM di Ambon, 2015-2019 
(1). Pengawasan terhadap penyelenggaraan perlindungan konsumen serta penerapan ketentuan peraturan perundang-undangannya

diselenggarakan oleh pemerintah, masyarakat, dan lembaga perlindungan konsumen swadaya masyarakat.

(2). Pengawasan oleh pemerintah sebagaimana dimaksud pada ayat (1) dilaksanakan oleh menteri dan/atau menteri teknis terkait.

(3). Pengawasan oleh masyarakat dan lembaga perlindungan konsumen swadaya masyarakat dilakukan terhadap barang dan/atau jasa yang beredar di pasar.

(4). Apabila hasil pengawasan sebagaimana dimaksud pada ayat (3) ternyata menyimpang dari peraturan perundang-undangan yang berlaku dan membahayakan konsumen, menteri dan/atau menteri teknis mengambil tindakan sesuai dengan peraturan perundang-undangan yang berlaku.

(5). Hasil pengawasan yang diselenggarakan masyarakat dan lembaga perlindungan konsumen swadaya masyarakat dapat disebarluaskan kepada masyarakat dan dapat disampaikan kepada menteri dan menteri teknis.

(6). ketentuan pelaksanaan tugas pengawasan sebagaimana dimaksud pada ayat (1), ayat (2), dan ayat (3) ditetapkan dengan peraturan pemerintah.

Berdasarkan ketentuan pasal 30 UUPK, maka diketahui bahwa pemerintah bertindak sebagai pengayom masyarakat dan juga sebagai pembina pelaku usaha dalam meningkatkan kemajuan industri dan perekonomian negara. Salah satu bentuk perlindungan konsumen yang tidak kalah pentingnya diberikan oleh BPOM Provinsi Maluku adalah dengan melakukan pengawasan pada penerapan peraturan-peraturan, ataupun standar yang telah ada.

Namun pengawasan BPOM hanya terbatas pada obat, obat tradisional, suplemen kesehatan, kosmetik dan makanan, serta pengawasan terhadap bahan berbahaya (terkait dengan produk pangan olahan kemasan). Tidak termasuk pada penggunaan plastik sebagai wadah pembungkus makanan yang biasa dipakai oleh para pelaku usaha restoran maupun pelaku usaha makanan siap saji di kota Ambon.

Jika dilihat terkait dengan pengawasan terhadap bahan berbahaya, semestinya tidak hanya terbatas pada kemasan produk pangan olahan saja, melainkan kepada semua jenis kemasan yang dipakai untuk membungkus makanan baik itu makanan yang dingin maupun yang panas. Hal ini dipertegas dalam Undang-Undang Nomor 18 Tahun 2012 tentang pangan yaitu pasal 82 (ayat 1 dan 2) dan pasal 83 (ayat 1).

Pasal 82 ayat (1) mengatur bahwa "Kemasan pangan berfungsi untuk mencegah terjadinya pembusukkan dan kerusakan, melindungi produk dari kotoran, dan membebaskan pangan dari jasad renik patogen". Sedangkan ayat (2) mengatur bahwa "Setiap orang yang melakukan produksi pangan dalam kemasan wajib menggunakan bahan kemasan pangan yang tidak membahayakan kesehatan manusia".

Pasal 83 ayat (1) "setiap orang yang melakukan produksi pangan untuk diedarkan dilarang menggunakan bahan apapun sebagai kemasan pangan yang dapat melepaskan cemaran yang membahayakan kesehatan manusia".

Selain itu juga dipertegas dalam Peraturan Pemerintah Nomor 28 Tahun 2004 tentang keamanan, mutu dan gizi pangan. Yaitu pada pasal 16 ayat (1), 
pasal 17 ayat (1), dan pasal 19 ayat (1). Pasal 16 ayat (1): "setiap orang yang memproduksi pangan untuk diedarkan dilarang menggunakan bahan apapun sebagai kemasan pangan yang dinyatakan terlarang dan/atau yang dapat melepaskan cemaran yang merugikan atau membahayakan kesehatan manusia". Pasal 17 ayat (1): "setiap orang yang memproduksi pangan untuk diedarkan wajib menggunakan bahan kemasan yang diizinkan". Pasal 19 ayat (1): "setiap orang yang melakukan produksi pangan yang akan diedarkan wajib melakukan pengemasan pangan secara benar untuk menghindari terjadinya pencemaran terhadap pangan".

Regulasi terkait penggunaan wadah kemasan sudah sangat jelas, itu artinya bukan hanya saja terhadap kemasan pangan olahan saja yang menjadi salah satu produk yang diawasi oleh BPOM tetapi semua produksi pangan termasuk didalamnya adalah makanan siap saji. Jelas terlihat bahwa aturan melarang penggunaan wadah berbahaya karena akan membahayakan kesehatan manusia. Oleh karena itu BPOM selaku perpanjang tangan dari pemerintah, semestinya dalam menjalankan fungsi dan kewenangannya harus memperhatikan setiap aturan-aturan yang berkaitan dengan bidang pengawasannya. Bukan hanya saja pada makanan tetapi juga pada kemasan yang dipakai sebagai wadah pembungkus.

Selain BPOM, tanggung jawab yang besar juga harus dipikul oleh Dinas Perindustrian dan Perdagangan khususnya Bidang Perlindungan Konsumen. Tanggung jawab mereka semestinya tidak hanya terbatas pada peredaran produk yang berlogo SNI (Standar Nasional Indonesia) saja, tetapi semua produk termasuk plastik.

Memang pemerintah tidak bisa melarang produsen plastik untuk menghentikan produksi plastik, karena mereka pasti dapat berdalil bahwa, produksi plastik tidak untuk membungkus makanan tetapi sebagai pembungkus produk lain. Namun yang dituntut disini adalah tanggungjawab penerintah (BPOM dan Dinas Perindustrian dan Perdagangan khususnya Bidang Perlindungan Konsumen) untuk meningkatkan pengawasan kepada pelaku usaha restoran maupun pelaku usaha makanan siap saji terkait wadah yang mereka pakai untuk membungkus makanan.

Disamping pemerintah, pelaku usaha juga memiliki tanggung jawab. Disini dituntut pengetahuan dan kesadaran dari pelaku usaha dalam memilih wadah yang dipakai untuk membungkus makanan yang akan dibeli oleh konsumen. Sebagaimana yang telah dijelaskan sebelumnya bahwa tanggungjawab yang dibebankan kepada pelaku usaha adalah tanggung jawab atas dasar kesalahan dan tanggung jawab mutlak. Tanggung jawab atas dasar kesalahan dapat dibebankan kepada pelaku usaha apabila pelaku usaha melakukan kesalahan yang merugikan orang lain. Sedangkan tanggung jawab mutlak yaitu pelaku usaha langsung bertanggung jawab sebagai resiko usahanya. Oleh karena itu, bagi pelaku usaha yang menggunakan wadah plastik yang berbahaya bagi keselamatan manusia, maka terhadap dia dapat dituntut pertanggungjawaban.

Prinsip tanggung jawab pelaku usaha diatur dalam Pasal 19 Undang-Undang Perlindungan Konsumen, yaitu :

a. Pelaku usaha bertanggung jawab memberikan ganti rugi atas kerusakan, pencemaran, atau kerugian konsumen akibat mengkonsumsi barang atau jasa yang dihasilkan atau diperdagangkan.

b. Ganti rugi sebagaimana dimaksud pada ayat (1 ) dapat berupa pengembalian uang atau penggantian barang atau jasa sejenis setara ini lainnya, atau perawatan kesehatan atau jasa yang sejenis atau setara ini lainnya, atau perawatan kesehatan atau pemberian santunan yang sesuai dengan ketentuan 
peraturan perundang-undangan yang berlaku.

c. Pergantian ganti rugi dilaksanakan dalam tenggang waktu 7 hari setelah tanggal transaksi.

d. Pemberian ganti rugi sebagaimana dimaksud pada ayat (1) dan ayat (2) tidak menghapuskan kemungkinan adanya tuntutan kesalahan.

e. Ketentuan sebagaimana dimaksud pada ayat (1) dan ayat (2) tidak berlaku apabila pelaku usaha dapat membuktikan bahwa kesalahan tersebut merupakan kesalahan konsumen.

\section{Perlindungan Hukum Bagi Konsumen Terkait Dengan Penggunaan Wadah Plastik Berbahaya}

Berdasakan Pasal 1 angka 1 Undang-undang nomor 8 tahun 1999 Tentang Perlindungan Konsumen, Perlindungan Konsumen adalah Segala upaya yang menjamin adanya kepastian hukum untuk memberi perlindungan kepada konsumen.

Upaya perlindungan konsumen di Indonesia didasarkan pada sejumlah asas dan tujuan yang telah diyakini bisa memberikan arahan dalam implementasinya di tingkatan praktis. Dengan adanya asas dan tujuan yang jelas, hukum perlindungan konsumen memiliki dasar pijakan yang benar-benar kuat.

Didalam Pasal 2 Undang-undang Perlindungan konsumen, asas perlindungan konsumen meliputi:

a. Asas manfaat, Maksud asas ini adalah untuk mengamanatkan bahwa segala upaya dalam penyelenggaraan perlindungan konsumen harus memberikan manfaat sebesar-besarnya bagi kepentingankonsumen dan pelau usaha secara keseluruhan. b. Asas keadilan, Asas ini dimaksudkan agar partisipasi seluruh rakyat bias diwujudkan secara maksimal dan memberikan kesempatan kepada konsumen dan pelaku usaha untuk memperoleh haknyadan melaksanakan kewajibannya secara adil.

c. Asas keseimbangan, Asas ini dimaksudkan untuk memberikan keseimbangan antara kepentingan konsumen, pelaku usaha, dan pemerintah dalam arti material maupun spiritual.

d. Asas keamanan dan keselamatan konsumen, Asas ini dimaksudkan untuk memberikan jaminan atas keamanan dan keselamatan kepada konsumen dalam penggunaan, pemakaian, dan pemanfaatan barang/jasa yang dikonsumsi atau digunakan.

e. Asas kepastian hukum, Asas ini dimaksudkan agar baik pelaku usaha maupun konsumen menaati hukum dan memperoleh keadilan dalam penyelenggaraan perlindungan konsumen, serta Negara menjamin kepastian hukum.

Pasal 3 Undang-undang Perlindungan Konsumen, disebutkan bahwa tujuan perlindungan konsumen adalah sebagai berikut :

a. Meningkatkan kesadaran, kemampuan, dan kemandirian konsumen untuk melindungi diri.

b. mengangkat harkat dan martabat konsumen dengan cara menghindarkannya dari ekses negatif pemakaian barang dan/atau jasa.

c. Meningkatkan pemberdayaan konsumen dalam memilih, dan menuntut hak- haknya sebagai konsumen.

d. Menciptakan sistem perlindungan konsumen yang mengandung unsur kepastian hukum dan keterbukaan informasi serta akses untuk 
mendapatkan informasi.

e. Menumbuhkan kesadaran pelaku usaha mengenai pentingnya perlindungan konsumen sehingga tumbuh sikap yang jujur dan bertanggung jawab dalam berusaha.

f. Meningkatkan kualitas barang/jasa yang menjamin kelangsungan usaha produksi barang dan jasa, kesehatan, kenyamanan, keamanan, dan keselamatan konsumen.

Perlindungan terhadap konsumen harus menjadi perhatian yang serius oleh pemerintah khususnya pada produk pangan yang beredar di lingkungan masyarakat, karena para konsumen dan masyarakat pada umumnya adalah korban dari pihak produsen yang tidak bertanggung jawab. Oleh Karena itu, pemerintah wajib memberi perhatian khusus pada kegiatan perdagangan nasional. UUPK diharapkan dapat menciptakan kegiatan usaha perdagangan yang adil tidak hanya bagi kalangan pelaku usaha, melainkan secara langsung untuk kepentingan konsumen, baik selaku pengguna, pemanfaat maupun pemakai barang dan/atau jasa yang ditawarkan oleh pelaku usaha.

Pemerintah dalam upaya perlindungan konsumen mempunyai peran yang penting selaku penengah di antara kepentingan pelaku usaha dan kepentingan konsumen, agar masing-masing pihak dapat berjalan seiring tanpa saling merugikan satu sama lain. Pemerintah harus bertanggung jawab atas pembinaan dan penyelenggaraan perlindungan konsumen, untuk menjamin diperolehnya hak konsumen dan pelaku usaha serta dilaksanakannya kewajiban konsumen dan pelaku usaha sebagaimana diatur dalam pasal 29 dan pasal 30 UUPK. Peran pemerintah sebagai pengawas merupakan fungsi yang penting untuk melindungi masyarakat dari bahan kimia yang terkandung dalam plastik. Tanpa ada pengawasan yang baik, dikhawatirkan konsumen tidak akan terlindungi dari bahan berbahaya tersebut.

Perlindungan terhadap konsumen yang dilakukan oleh pemerintah dalam hal pembinaan dan pengawasan. Berdasarkan ketentuan pasal 2 Peraturan Pemerintah Nomor 58 Tahun 2001 tentang Pembinaan Dan Pengawasan Penyelenggaraan Perlindungan Konsumen, dikatakan bahwa pemerintah bertanggung jawab atas pembinaan perlindungan konsumen yang menjamin diperolehnya hak konsumen dan pelaku usaha serta dilaksanakannya kewajiban konsumen dan pelaku usaha. Sedangkan dalam hal pengawasan pemerintah diatur lebih lanjut dalam ketentuan pasal 7 dalam Peraturan Pemerintah yang sama. Bahwa dikatakan pengawasan terhadap penyelenggaraan perlindungan konsumen dan penerapan ketentuan peraturan perundang-undangannya dilakukan oleh pemerintah, masyarakat dan lembaga perlindungan konsumen swadaya masyarakat.

Dengan demikian menjadi jelas, bahwa pemerintah memiliki tanggung jawab untuk melindungi masyarakat sebagai konsumen. Maka apabila ditinjau dari segi hak dan tanggung jawab dimana masyarakat sebagai konsumen harus dilindungi oleh pemerintah, maka hal ini sejalan sebagaimana diatur dalam ketentuan pasal 29 UUPK.

\section{P E N U T U P}

Bentuk pelaksanaan fungsi dan
peran BPOM berupa himbauan,
sosialisasi dan edukasi kepada pelaku
usaha. Cakupan pengawasan BPOM
hanya terhadap olahan pangan
berkemasan, obat-obatan farmasi maupun
tradisional, dan kosmetik. Terkait dengan
penggunaan wadah plastik sebagai
wadah pembungkus makanan bukanlah
merupakan cakupan pengawasan mereka.
Demikian juga dengan Dinas
Perindustrian dan Perdagangan Bidang


Perlindungan Konsumen. Cakupan pengawasan mereka hanya pada produk yang berlogo SNI (Standar Nasional Indonesia).

Penggunaan wadah plastik untuk pembungkus makanan banyak dipakai oleh pelaku usaha restoran maupun pelaku usaha makanan siap saji karena keunggulannya yaitu, harganya murah, praktis, ringan dan tidak ketinggalan zaman. Kesadaran pelaku usaha dan konsumen terhadap bahaya penggunaan wadah plastik belum ada karena masih kurangnya pengetahuan akan bahaya wadah plastik tersebut. Oleh karena itu saran yang ingin disampaikan adalah:

1. BPOM dalam menjalankan fungsi dan kewenangannya harus memperhatikan setiap aturan-aturan yang berkaitan dengan bidang pengawasannya. Bukan hanya saja pada makanan tetapi juga pada kemasan yang dipakai sebagai wadah pembungkus. Tanggung jawab Dinas Perindustrian dan Perdagangan khususnya Bidang Perlindungan Konsumen semestinya tidak hanya terbatas pada peredaran produk yang berlogo SNI (Standar Nasional Indonesia) saja, tetapi semua produk termasuk plastik.

2. Himbauan kepada pelaku usaha untuk tidak menggunakan plastik dapat dilakukan dengan cara menempel stiker atau panflet terkait penggunaan wadah plastik sebagai pembungkus makanan di setiap tempat-tempat usaha makanan. Sehingga bukan saja dilihat oleh pelaku usaha tetapi juga oleh konsumen.

Pelaku usaha dapat menjalankan tanggungjawabnya dengan baik dan benar, dengan tidak berlaku curang kepada konsumen sesuai dengan Undang-undang Nomor 8 tahun 1999 Tentang Perlindungan Konsumen.

\section{DAFTAR PUSTAKA}

Z. Nasution, Hukum Perlindungan Konsumen Suatu Pengantar, Diadit Media, Jakarta, 2002

Andi Hamzah, Kamus Hukum, Ghalia Indonesia, 2005

Banbang Waluyo, Penelitian Hukum, PN, Sinar Grafika, Jakarta, 1991

Endang Sri Wahyuni, Aspek hukum Sertifikasi dan Keterkaitannya dengan Perlindungan Konsumen, PT. Citra Aditya Bakti, Bandung, 2003

J. Supranto, Metode penelitian dan Statistik, Rineka Cipta, Jakarta, 2003

Jhon Pieris dan Wiwik Sri Widiarty, Negara Hukum dan Perlindungan Konsumen, Pelangi Cendekia, Jakarta, 2007

Jhonny Ibrahim, Teori dan Metodologi Penulisan hukum Normatif, Banyumedia Publishing, Malang, 2012

N. H. T. Siahaan, Hukum Konsumen: Perlindungan Konsumen dan Tanggung Jawab Produk, Panta Rei, Jakarta, 2005

Nurhayati Abbas, Tanggungjawab Produk Terhadap Konsumen dan Implementasi Pada Produk Pangan, AS Publishing, Makassar 2011

Sidharta, Hukum Perlindungan Konsumen Indonesia, Grasindo, Jakarta. 2000

Susanti Nugroho, Proses penyelesaian Sengketa Konsumen Ditinjau Dari Hukum Acara Secara Kendala Implementasinya, Kencana, Jakarta, 2008

Soekidjo Notoatmojo, Etika dan Hukum 
Kesehatan, Rineka Cipta, Jakarta, 2010

Titik Triwulan dan Shinta Febrian, Perlindungan Hukum Bagi Pasien, Prestasi Pusaka, Jakarta, 2010

Kitab Undang-Undang Hukum Perdata (KUHP)

Undang-Undang Nomor 8 Tahun 1999 Tentang Perlindungan Konsumen

Undang-Undang Nomor 18 Tahun 2012 tentang Pangan

Peraturan Pemerintah Nomor 28 Tahun 2004 tentang Keamanan, Mutu, dan Gizi pangan

Kemasan plastik Tidak Selalu Aman, http://antaranews.com,

Mujahidin Neo, Jenis-Jenis Plastik Menurut Kadar Kimia Yang Membahayakan Bagi Tubuh, http://aryafatta.wordpress.com,

Produk Plastik Berbahaya, http://indosiar.com,

Sutrisno Koswara, "Bahaya Dibalik Kemasan Plastik", <ebookpangan.com>

Sapto Nubroho Adi, “Ancaman polimik Sintetik Bagi Kesehatan Manusia",

http://www.chem-ia-try.org/?sect=articel $\underline{\text { \&ect }=69}$

http://pengetahuanumum.wordpress.com, 